\title{
The Implementation of Character Education in the Civics Education Syllabus at SMA Negeri 1 Sleman
}

\author{
T Heru Nurgiansah ${ }^{1)}$, Jagad Aditya Dewantara ${ }^{2)}$, Fazli Rachman ${ }^{3)}$
}

Pancasila And Civic Education Study Program of the Faculty of Teacher Training and Education of Universitas PGRI Yogyakarta PGRI I Sonosewu street No. 117 Yogyakarta, Indonesia Universitas PGRI Yogyakarta, Indonesia ${ }^{1)}$

Pancasila And Civic Education Study Program of Universitas Tanjungpura ${ }^{2)}$

Prof. Dr. H. Hadari Nawawi, Bansir Laut street,Bansir Laut, sub-district of Pontianak Tenggara,city of Pontianak,Kalimantan Barat 78124

Pancasila and Citizenship Education Department, faculty of social sciences

Universitas Negeri Medan, Willem Iskandar Pasar V street, Medan Estate, city of Medan, Indonesia ${ }^{3)}$ nurgiansah@upy.ac.id ${ }^{1)}$,jagad02@ fkip.untan.ac.id ${ }^{2}$, fazli.rachman@unimed.ac.id ${ }^{3),}$

\begin{abstract}
Students ' behaviour lately is becoming more concerned with being far from virtue values, needing to improve students ' character to be better. This research aims to know: 1) The values of the character in the syllabus, 2) Implementation of character education in the PKn-bus, and 3) supporting factors and inhibiting the implementation of character education in PKn syllabus in SMA Negeri 1 Sleman. This research uses qualitative methods. Data retrieval is done with observation and interviews. PKn teacher at SMA Negeri 1 Sleman implements character education in PKn syllabus in the sidelines of the subject matter, provide for example, and habituation. The implementation of character education in syllabus is quite effective in forming students ' character, indicated by good student behavior during school. The contributing factor to the implementation of character education in syllabus is the teacher's cooperation in character education, support of the headmaster by providing literature, direction and coaching, as well as the instruction of 18 character values that must be applied. The factor is that when there is solid material, the teacher sometimes forgot and did not get to instill the character values related to the material. Teachers need to plan learning better, so that the subject matter can be completed and character planting is also possible.
\end{abstract}

Keywords: Character Education, Citizenship Education.

\begin{abstract}
Abstrak. Perilaku siswa akhir-akhir ini semakin memprihatinkan yang jauh dari nilai-nilai kebajikan, perlu perbaikan karakter siswa agar menjadi lebih baik. Penelitian ini bertujuan untuk mengetahui : 1) nilai-nilai karakter yang ada dalam silabus PKn, 2) implementasi pendidikan karakter dalam silabus PKn, dan 3) faktor pendukung dan penghambat implementasi pendidikan karakter dalam silabus PKn di SMA Negeri 1 Sleman. Penelitian ini menggunakan metode kualitatif. Pengambilan data dilakukan dengan observasi dan wawancara. Guru PKn di SMA Negeri 1 Sleman mengimplementasikan pendidikan karakter dalam silabus PKn di sela menerangkan materi pelajaran, memberikan keteladanan, dan pembiasaan-pembiasaan. Implementasi pendidikan karakter dalam silabus cukup efektif membentuk karakter siswa, diindikasikan dengan perilaku siswa yang baik selama di sekolah. Faktor pendukung implementasi pendidikan karakter dalam silabus adalah kerja sama guru dalam pendidikan karakter, dukungan kepala sekolah dengan menyediakan literatur, arahan dan pembinaan, serta adanya petunjuk 18 nilai karakter yang harus diterapkan. Faktor penghambatnya adalah apabila terdapat materi yang padat, sehingga guru terkadang terlupa dan tidak sempat menanamkan nilai-nilai karakter yang berkaitan dengan materi tersebut. Guru perlu merencanakan pembelajaran secara lebih baik, sehingga materi pelajaran dapat diselesaikan dan penanaman karakter juga dapat dilakukan.
\end{abstract}

Kata Kunci: Pendidikan Karakter; Pendidikan Kewarganegaraan 


\section{INTRODUCTION}

A great and respected nation certainly has to have a strong character and distinguish it from other nations so that it becomes a nation that has dignity and dignity. Therefore citizenship education and religious education must be taught at all levels of education, from basic education to higher education (Megawangi, 2010; the Republic of Indonesia, 2003). Even so, the behavior of the Indonesian people is still not in accordance with applicable moral principles. Many people's behaviors are contrary to the norms prevailing in society, for example, the behavior of adolescents who like to cheat, the habit of bullying in schools, brawls between students and between groups of people, including the behavior of adults who are also happy with conflict and violence so that people lose their sense of security, drugs, promiscuity, and rampant corruption behavior, it turns out that all the religious and moral knowledge acquired, has no impact on changes in Indonesian human behavior (Kurniawan, 2013; Megawangi, 2010). Though citizenship education and religious education are the most important things to shape the character of a good person. Even what is seen is that there are so many Indonesian people who are inconsistent, others are talked about, and their actions are different, like the hoaxes currently in circulation. One of the causes is television broadcasts and images in various print media that describe the behavior of the Indonesian people to become uncontrolled (Raharjo, 2010). So it can be said that this Indonesian nation has experienced alarming moral degradation from year to year (Aryanto, 2013).

If examined further, there is something wrong with understanding learning in schools, namely relying on memorization and the final results refer to mastery of the material, without seeing and assessing the effects of nurturant in the process for the development of affective dimensions (Budimansyah, 2015). Many people only rely on their knowledge and memorization to form good character, even though the character can only be formed with positive habituation, not only habituation but the surrounding environment can also shape the character of students (Dewantara, Efriani, Sulistyarini, \& Prasetiyo, 2020). This positive habit is not enough to be developed in the family environment, but at school, it develops habits for students to develop their positive character.

It's just that the learning process still emphasizes mastery of the material and more visible is the evaluation target which still relies on the numbers showing that the concept of education is still focused on increasing the cognitive dimension, but weak on other dimensions, such as psychomotor and affective. Nationally, educational success is measured through testing material that only contains cognitive aspects. This was proven in the implementation of the National Examination. While other education, such as 
morals, violence, has not been touched. Education or education is not only limited to transferring knowledge but further and understanding that the more important thing is to be able to change or shape a person's character and character to be better, more polite in the ethical and aesthetic levels and behavior in everyday life (Bambang Nurokhim, 2010: 1). Education is a pattern of life that cannot be abandoned and underestimated, education itself is not only to form intellectuals but also to form human beings who are noble and useful to others (Safitri: 2018).

In the Law on Teachers and Lecturers, it is stated that the teacher is a professional educator with the main task of educating, teaching, guiding, directing, training, evaluating, and evaluating students in early childhood education through formal education, basic education, and secondary education. The task of educating teachers means implementing mentoring to students so that they behave and have good character, the teacher becomes a role model so that the students set an example. Besides, the next task of the teacher is to teach, the process of transforming knowledge to students so that the cognitive aspect increases. Students are likened to an empty glass, so with the teaching activities with the teacher, the empty glass becomes filled with water. According to Tabularasa's theory, it is said that the child is like a blank white paper, so with the entry of the lesson the paper contains scribbles of understanding knowledge.

The next task of the teacher is to guide and direct the students to stay in the corridor they should so that students do not make deviations, violations and mistakes that can harm themselves or others, this is where the important role of counseling guidance of a teacher who understands the psychological condition of children or students. Then a teacher must be able to train their students to have skills based on their interests and talents. Without having the skills a student can't be able to compete with the outside world. Last is to assess and evaluate students whether the subject matter delivered is well absorbed or even none of the material understood by students. In teaching and learning activities students must present their souls and minds in the classroom so that the focus is on what is conveyed by the teacher (Nurgiansah: 2019, 99).

Character education is a good solution to be implemented to form a strong character of the younger generation. Through the application of character education, it is expected that social problems that are motivated by capital degradation can be immediately addressed properly. Aunillah (2011) says that character education is a unitary system that instills and fosters whole character values in students, in which there are various elements, such as knowledge of good and bad, individual awareness of themselves 
and others, determination persistent, as well as the will, ability and action to be able to carry out values, both towards God Almighty, towards himself and others and the surrounding environment so that it becomes a useful community for the homeland and the nation.

Character education can be regarded as a unit that is run by the education curriculum program. Therefore this character education program is documented integrated into the 2013 curriculum. Not all schools and teachers can create a syllabus that is well and correctly characterized. A good understanding of the concept of character education and the values that must be embedded in character education is needed. The actualization of the basic values of character education in the education process is done through modeling or emulating, giving examples, reprimanding, informing, giving sanctions, and giving assignments (Sudiyono, 2011).

Exemplary teachers are very important in shaping the character of their students. The term teacher innocent and imitated means the teacher as a figure that will be emulated by students. The teacher can not only order to do something for students but must also set a good example. Being a teacher is not just a profession that produces but more than that that the teacher is a favorite figure who deserves to be a figure forming student identity. Exemplary means the key to success, including the success of a teacher in educating students in school. Exemplary as a foundation for a teacher to emulate good to students. Thus even the Prophet. it is illiterate but is aware of the importance of teaching to uphold the degree of social and the importance of the scientists keeping a great position because they are role models. Thus the example is the key to success, including the success of a teacher in educating students. With the teacher's example, students will respect the teacher and pay attention to the lesson so that there are no more cases or news about student violence against the teacher or vice versa teacher behavior that runs out of patience in guiding and directing students to be better. The phenomenon of violence perpetrated by students both against fellow students or the teacher is the result of the failure of good character formation towards students. The task of the teacher as a role model means also as a motivator that is motivating students so that the spirit of participating in learning in class and the teacher as a facilitator that is facilitating the facilities and infrastructure needed in learning activities. Thus, the synchronization between the role of the teacher and the school can shape the character of students one of them by including character education in the syllabus of Civics Education subjects.

\section{RESEARCH METHODS}

The research method was a way or step that were passed or carried out by a researcher 
to collect data as information both primary and secondary which were all needed to support data to solve problems that occur in the field.

This research used a qualitative method. According to Tohirin (2013: 2), qualitative research was research that used a naturalistic approach to search for and find an understanding of phenomena in a particular setting. The time used in this research is 2 (two) months, namely October and November 2019. The method chosen was a qualitative approach with a descriptive design. Qualitative research was chosen because this research seeks to collect data in a natural environment (Creswell, 2015). The natural environment was very supportive of a descriptive study because it described in full the existing facts. While the descriptive design was intended to describe the results of research (Mardalis, 2010). The place/location of the research used in this study was SMA Negeri 1 Sleman Yogyakarta. The informants in this study were three Civics teachers, school principals, and three students. The source of data in this study was documentation that shows the implications of character education in the PKN syllabus in SMA Negeri 1 Sleman.

\section{DISCUSSION}

\begin{tabular}{|c|c|}
\hline Core Competencies & $\begin{array}{c}\text { The } \\
\text { Application }\end{array}$ \\
\hline $\begin{array}{l}\text { Respect and appreciate } \\
\text { the teachings of the } \\
\text { religion they hold }\end{array}$ & $\begin{array}{lr}\text { Foster } & \text { an } \\
\text { attitude } & \text { of } \\
\text { tolerance } & \\
\text { between } & \\
\text { students } & \text { with }\end{array}$ \\
\hline
\end{tabular}

\begin{tabular}{|c|c|}
\hline & $\begin{array}{l}\text { different } \\
\text { beliefs }\end{array}$ \\
\hline 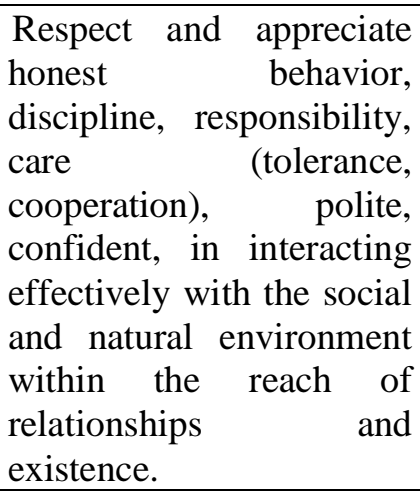 & $\begin{array}{l}\text { Get in the } \\
\text { habit of telling } \\
\text { the truth, } \\
\text { helping one } \\
\text { another, } \\
\text { preserving the } \\
\text { environment. }\end{array}$ \\
\hline $\begin{array}{l}\text { Understanding knowledge } \\
\text { (factual, conceptual, and } \\
\text { procedural) based on } \\
\text { curiosity about science, } \\
\text { technology, art, culture } \\
\text { related to phenomena and } \\
\text { events seen in the eye. }\end{array}$ & $\begin{array}{l}\text { Develop } \\
\text { knowledge- } \\
\text { based on } \\
\text { technological } \\
\text { tools such as } \\
\text { internet use } \\
\text { and social } \\
\text { media }\end{array}$ \\
\hline $\begin{array}{l}\text { Trying, processing, and } \\
\text { presenting in the realm of } \\
\text { concreter } \\
\text { unraveling, composing, } \\
\text { modifying, and making) } \\
\text { and abstract domains } \\
\text { (writing, reading, } \\
\text { calculating, drawing and } \\
\text { composing) following } \\
\text { what is learned in school } \\
\text { and other sources in the } \\
\text { same perspective /theory }\end{array}$ & $\begin{array}{l}\text { Critical, } \\
\text { analytical and } \\
\text { argumentative } \\
\text { thinking. }\end{array}$ \\
\hline
\end{tabular}

Source: processed by researchers (2019)

The first application is to foster an attitude of tolerance between students of different beliefs, this can be seen from the habits of students who have been well programmed by schools such as duha prayer and midday prayer. Although not all students in SMA Negeri 1 Sleman are Muslim, students of different faiths do not mind it.

The second application is getting used to telling the truth, helping one another, preserving the environment. Not only is 
saying, but the honest character is also practiced in daily behavior. This was stimulated by the existence of an honesty canteen, although initially, the existence of the canteen caused material losses because some students had not behaved honestly but gradually the honest attitude of students was increasingly formed. Furthermore, helping friends and preserving and protecting the environment. The availability of rubbish bins in the school environment is a driving factor for students not to litter.

Furthermore, developing science-based on technological tools such as the use of the internet and social media is a priority of students today so special attention is needed on how students can implement and implement the internet for positive activities. With the internet making students not technologically illiterate, their hopes are capable of social media wisely, avoiding provocation and hoaxes, bullying, and others that are not useful.

Finally, critical thinking and argumentative thinking. This is intended so that students have a soul of concern and high sensitivity. Indifferent to the phenomena that occur at this time. Students are able to assess each incident and background events. In the opinion of Johnson (2010: 187) critical thinking skills are the ability to think well, and to think about the thought process is part of thinking well. Critical thinking skills need to be developed since students sit in elementary school. Because critical thinking skills must be honed early so that students are accustomed to critical and creative thinking patterns.

According to Krulik \& Rudnick (in Siswono, 2011) in general, thinking skills consist of four levels, namely: memorizing (recall thinking), basic (basic thinking), critical (critical thinking), and creative (creative thinking). The lowest level of thinking is memorization skills (recall thinking) which consist of skills that are almost automatic or reflexive. The next level of thinking is basic skills.

Based on the results of interviews and observations that all teachers include character values in the syllabus Civics that he made. Character values instilled in elementary school lessons refer to 18 character values set by the Ministry of National Education in 2010 (Komalasari \& Saripudin, 2017; Kurniawan, 2013; Naim, 2012). The teacher then adjusts the characters developed with the subject matter and not all are implanted through Civics subjects. Broadly speaking, the character values embedded in Civics courses are religious, disciplined, and independent.

Integrating characters in Civics learning can be done by determining the learning steps and materials that are following the characters developed. Quality character development starts in the early stages of learning design (Prastyo, 2012). Therefore, the implementation of character development can be integrated into the syllabus as practiced by Civics teachers in SMA N 1 Sleman. The 
teacher designs the Civics learning in the syllabus by including the Cultural Values and Nation Character (NBKB) they made. NBKB in the syllabus is included in each basic competency, except for one syllabus that is listed on the last page of the syllabus table by describing the expected student character. Therefore, the NBKB was found in a special syllabus column and also listed at the bottom of the subject matter.

Based on the results of interviews and observations, the teacher implements character education in Civics learning by instilling character values when describing subject matter adapted to the character to be achieved, giving an example to students about behavior that is following the student's character, and making habituation of behavior that is both according to the character that is implanted. The implementation of character education in learning is quite effective in shaping student character, indicated by good student behavior during school.

According to Ulwan (in Rachman \& Hijran, 2017), modeling is a method of character development with students by displaying examples of characters. Delinquency is a medium with a convincing success rate. The influence of role models in education must be realized as having a relatively high positive impact (Schaefer, 1994).

Supporting factors for the implementation of character education in the syllabus is the cooperation of teachers together to shape the character of students in school through exemplary or advising students who exhibit behavior that does not fit the expected character. Besides, there is also the support of the principal by providing a variety of character education literature, direction, and coaching, as well as the existence of 18 character values that must be applied in SMA $\mathrm{N} 1$ Sleman. The inhibiting factor is that if there is a dense material, so the teacher sometimes forgets there is no time to instill the character values associated with the material. On these materials, the teacher needs to plan to learn better, so that the subject matter can be completed and the cultivation of character can also be done.

The results showed that all teachers included character values in the Civic Education syllabus that they made, even though some did not include each basic competency. Character values embedded in the lessons refer to 18 character values determined by the Ministry of National Education and then adjusted to the subject matter and not all are instilled through Civics subjects. Broadly speaking, the character values that are embedded in Civics subjects are religious, honest, disciplined, responsibility, tolerance, hard work, independent, creative, democratic, national spirit, love of the motherland, respect for achievement, love for peace, care environment, and social care. 
Religious character means being a devout person in worshiping God, having an attitude of tolerance towards different beliefs, and striving to live in harmony with people of different religions. Examples of implementation are always praying before the lesson starts and after the lesson finishes at the last hour.

Honest character means to speak as it is without exaggerating to get praise from others. Students with honest character will be humble. Students who have honest character will always do good deeds because honesty will coexist with virtue.

The honest character that exists in children from an early age will be very influential and become a benchmark for their development later when they become adults and carry out community life. Discipline character means always obeying the rules and not having the intention to try to break them. Always arrive on time and try not to be late, always live regularly scheduled in their daily routine, and always carry out the task as well as possible.

The Character of Responsibility means being aware of the task and trying to carry it out voluntarily. According to Narwanti (2011: 30) in Fitriastuti (2014) responsibility is the attitude and behavior of a person to carry out their duties and obligations, which he should do without the need to be governed again, towards oneself, society, environment (natural, social, and cultural), Country and
God Almighty. According to Aziz (2012) in Pasani, et al (2016), responsibility must start from giving tasks that look easy and trivial but are carried out continuously. For example, not throwing trash in the classroom or just any place. There is no need for sanctions for this learning, just enough students will grow in awareness of the task. So that the task finally turned into the obligation to dispose of garbage in its place. And this must be forced because the proverb says ordinary because forced.

The character of hard work means unyielding and persistent in running something. Hard work is an activity that is done in earnest without tiring or stopping before the work target is reached and always prioritizes or pays attention to the satisfaction of the results on every activity carried out. Hard work can be interpreted as working to have a serious nature to achieve the goals to be achieved. They can utilize the optimal time so that sometimes they don't recognize the time, distance, and difficulties they face. Hard work means being enthusiastic and trying hard to achieve good and maximum results. With hard work, the declared target will be achieved because it can analyze everything that can hinder the goal.

The character of caring for the environment is an attitude and action that always seeks to prevent damage to the surrounding natural environment and develop efforts to repair natural damage that has already occurred such as planting trees. 
The independent character teaches students not to depend on others. Creative characters are able to foster breakthroughs and discoveries that are different from before. Democratic character means students learn to accept differences and not force their will in the sense of prioritizing the interests of groups or groups rather than their interests. The character of rewarding achievement means that students have attitudes and actions that encourage themselves to produce something useful for the community and recognize and respect the successes obtained by others. The character of the love of the motherland Loves the motherland is an attitude and behavior that shows a sense of pride, loyalty, care and high respect for language, culture, economy, politics and so on, so it is not easy to accept the offer of other nations that can harm the nation itself. The character of social care means the attitudes and actions that always want to assist others and communities in need. This social care is the implementation of human consciousness as social beings who cannot live alone. Humans as social beings mean that they cannot live alone, needing each other's help.

The cultivation of positive character values is very important in formalized education in primary schools. This sees the occurrence of various events that are not following cultural values and national character. Many have been seen on television news about cases of violence in lessons, crime, and conflict over regional head elections that lead to physical fighting between supporters groups, even fights between members of Parliament because of differences of opinion between them. The above phenomenon will not occur if the community has, holds fast, and implements cultural values and national character.

The results showed that the teacher implements character education in the Civic Education syllabus between explaining the subject matter, by giving an example to students about behavior that is following the student's character, as well as making good behavior habituations according to the embedded character. Implementation of character education in the syllabus is quite effective in shaping the character of students, indicated by good student behavior while at school. Supporting factors for the implementation of character education in the syllabus is the cooperation of teachers together to shape the character of students in school through exemplary or advising students who exhibit behavior that does not fit the expected character. Besides, there is also the support of the principal by providing a variety of character education literature, direction, and coaching, as well as the existence of 18 character values that must be applied in SMAN 1 Sleman. The inhibiting factor is that if there is a dense material, so the teacher sometimes forgets there is no time to instill the character values associated with the material. On these materials, the teacher needs to plan to learn 
better, so that the subject matter can be completed and the cultivation of character can also be done.

Planting character values will be effective if character education methods are applied appropriately. In the first stage, the character values are embedded according to the syllabus between the learning effectively and embedded in students' memories. Instilling character values in learning according to the syllabus will be more effective if there is an example from the teacher. Exemplary is one method that is the key to the success of inculcating values in character education. Students will learn more about what they see. The example of the teacher will be justification and at the same time strengthen the inculcation of character values in students' memories.

Implementation of character education requires good cooperation from the teacher. If teachers support each other by giving examples to all students and getting good behavior, nationalism behavior is also an important part so that students can become personal characters of Pancasila (Dewantara et al, 2018), then this will further support the effective inculcation of character values to students. Besides, teachers also need to understand well the various methods of applying character education and character values that must be instilled in students. The direction and guidance of the principal, and the provision of character education literature, will further enhance teachers' understanding of the application of character education in schools so that it can be better implemented by teachers.

\section{CONCLUSION}

Based on the results of research and discussion, the following conclusions can be drawn: All teachers at SMA N 1 Sleman include character values in the Civics syllabus that they make. Character values embedded in elementary school lessons refer to 18 character values determined by the Ministry of National Education and then adjusted to the subject matter and not all are instilled through Civics subjects.

The implementation of character education in the Civics syllabus in SMA N 1 Sleman, is done by including the cultural values and national character $(\mathrm{NBKB})$ in the Civics syllabus that he made.

The implementation of character education in Civics learning at SMA N 1 Sleman, is done by instilling character values in between explaining the subject matter adapted to the subject matter, giving an example to students about behavior that is following the student's character, as well as making good behavior habits in accordance the character implanted. The implementation of character education in learning is quite effective in shaping student character, indicated by good student behavior during school. 
The supporting factor for the implementation of character education in Civics Education is the cooperation of teachers together to shape the character of students in school through exemplary or advising students who exhibit behavior that is not following the expected character. Besides, there is also the support of the principal by providing a variety of character education literature, direction, and coaching, as well as the existence of 18 character values that must be applied in SMA N 1 Sleman. The inhibiting factor is if there is a dense material, so the teacher sometimes forgets not to instill the character values associated with the material.

\section{REFERENCES}

[1] Aryanto, R. (2013). Pelaksanaan Pembelajaran Pendidikan Kewarganegaraan Sebagai Pendidikan Karakter di SMAN 1 Cangkringan Kabupaten Sleman Yogyakarta. Universitas Negeri Yogyakarta.

[2] Aunillah, N. I. (2011). Panduan Menerapkan Pendidikan Karakter di Sekolah. Yogyakarta: Laksana.

[3] Bambang Nurokhim. (2010). Teropong Pendidikan Indonesia Menuju Bangsa Indonesia yang Berkarakter. dalam http://santosoeducation.blogspot.com.

[4] Budimansyah, D. (2015). Reposisi Peran pendidikan Kewarganegaraan untuk Penguatan Karakter Bangsa. In Sapriya, Syaifullah, M. M. Adha, \& C. Cuga (Eds.), Prosiding Seminar Nasional Penguatan Komitmen Akademik dalam Memperkokoh Jati Diri PKn (pp. 67-76). Bandung: Labolatorium Pendidikan Kewarganegaraan Departemen Pendidikan Kewarganegaraan FPIPS Universitas Pendidikan Indonesia.

[5] Creswell, J. W. (2015). Riset Pendidikan; Perencanaan, Pelaksanaan dan Evaluasi Riset Kualitatif \& Kuantitatif (Ke-5).
Yogyakarta: Pustaka Pelajar.

[6] Dewantara, J. A., Efriani, Sulistyarini, \& Prasetiyo, W. H. (2020). Optimization of Character Education Through Community Participation Around The School Environment ( Case Study in Lab School Junior High School Bandung ). Jurnal Etika Demokrasi, 5(1), 53-66.

[7] Dewantara, J, dan Budimansyah, D. (2018). Mutual Cooperation Based Go Green: New Concept Defense of Country. Paper Presented Advances in social science, Education and Humanities Research, 251, 3845, doi: 10.2991/acec-18.2018.10

[8] Fitriastuti dan Masduki. (2014). Peningkatan Sikap Kerja Keras Dan Tanggung Jawab Siswa Dalam Pembelajaran Matematika Melalui Strategi Course Review Horay. Skripsi. FKIP, Pendidikan Matematika. Universitas Muhammadiyah Surakarta.

[9] Jamal Ma'mur Asmani, Buku panduan Internalisasi Pendidikan Karakter di Sekolah(Jogjakarta: Diva Press, 2013), hlm. 71

[10] Johnson, T. E., Archibald, T. N., \& Tenenbaum, G. (2010). Individual and team annotation effects on students' reading comprehension, critical thinking, and metacognitive skills. Computers in Human Behavior, 26, 1496-1507.

[11] Komalasari, K., \& Saripudin, D. (2017). Pendidikan Karakter; Konsep dan Aplikasi Living Values Education. Bandung: P.T. Refika Aditama.

[12] Krulik, S \& Rudnick. (1999).'Innovative Taks to Improve Critical and Creative Thinking Skills. Develoving Mathematical Raesoning in Grades K-12”, pp.138-145.

[13] Kurniawan, S. (2013). Pendidikan Karakter: Konsepsi \& Implementasi secara Terpadu di Lingkungan Keluarga, Perguruan Tinggi, dan Masyarakat. Yogyakarta: Ar-Ruzz Media.

[14] Mardalis. (2010). Metode Penelitian: Suatu Pendekatan Proposal (Bumi Aksar). Jakarta.

[15] Megawangi, R. (2010). Pengembangan Program Pendidikan Karakter di Sekolah: 
Pengalaman Sekolah Karakter. Retrieved February 10, 2020, from http://repository.ut.ac.id/2486/1/fkip201002. pdf

[16] Naim, N. (2012). Character Building: Optimalisasi Peran Pendidikan dalam Pengembangan Ilmu \& Pembentukan Karakter. Yogyakarta: Ar Ruzz Media.

[17] Nurgiansah, T. H. (2019). Pemutakhiran Kurikulum Pendidikan Kewarganegaraan di Era Revousi Industri 4.0. Dalam A. Wahyudi, R. Nababan, \& F. Rachman (Editor), Prosiding Seminar Nasional: Reaktualisasi Konsep Kewarganegaraan Indonesia; Digital Library, 15 Oktober 2019 (hlm. 95-102). Medan: Fakultas Ilmu Sosial Universitas Negeri Medan.

[18] Pasani, dkk. (2016). Mengembangkan Karakter Tanggung Jawab Siswa Melalui Pembelajaran Model Kooperatif Tipe Number Head Together. Jurnal. Vol 4, No 22016

[19] Prastyo, A. T. (2012). Merancang Perencanaan Pembelajaran Berbasis Pendidikan Karakter. El-Hikmah, O(2), 220234.

[20] Rachman, F., \& Hijran, M. (2017). Kajian Keteladanan dalam Memperkuat Pendidikan Indonesia. The 5th University Research Colloquium: Cinta Negeriku, 998-1003. Yogyakarta: Universitas Ahmad Dahlan.

[21] Raharjo, S. (2010). Keluarga: Pembentuk Karakter Bangsa. Kusus: FKIP Universitas Muria Kudus.

[22] Republik Indonesia. (2003). Undang-Undang Republik Indonesia Nomor 20 Tahun 2003 Tentang Sistem Pendidikan Nasional. Jakarta: Sekretaris Negara Republik Indonesia.

[23] Safitri Mutiara Paradilla. (2018). Keteladanan Guru Sebagai Upaya Pembentukan Karakter Disiplin dan Tanggung Jawab Siswa Kelas Tinggi SDN 1 Simo Tahun Ajaran 2017/2018. Universitas Muhammadiyah Surakarta

[24] Schaefer, C. (1994). Bagaimana Mempengaruhi Anak. Semarang: Dahara Prize.

[25] Siswono, T. Y. E. 2011. Level of student's creative thinking in classroom mathematics. Journal Educational Research and Review. Vol. 6, No. 7, pp 548-553.

[26] Sudiyono. (2011). Aktualisasi Nilai-Nilai Dasar Pendidikan Karakter Guru SMP dan SMA di Kabupaten Sleman. Jornal Managemen Pendidikan, 1(8), 13-22.

[27] Tohirin. 2013. Metode Penelitian Kualitatif dalam Pendidikan dan Bimbingan Konseling. Jakarta: PT Raja Grafindo Persada. 